\title{
Zdzisław J. Kijas OFMConv
}

\section{Tadeusz Kałużny SCJ, Oikonomia kościelna w teorii i praktyce prawosławia, Kraków 2018, 276 s.}

To kolejna, trzecia wielka monografia krakowskiego profesora ks. Tadeusza Kałużnego SCJ, pracownika Uniwersytetu Papieskiego Jana Pawła II, kierownika Katedry Ekumenizmu. Również niniejsza dotyczy tematyki prawosławnej. Pierwszą, otwierającą teologiczny tryptyk, była pozycja Sekret Nikodema. Nieznane oblicze Rosyjskiego Kościoła Prawosławnego, rozprawa doktorska obroniona w Rzymie na Papieskim Instytucie Wschodnim (Kraków 1999). Drugą była monografia Nowy Sobór Ogólnoprawosławny. Natura, historia przygotowań, tematyka (Kraków 2008), opublikowana na kilka lat przed tym wielkim wydarzeniem, jakim był sobór panprawosławny, którego obrady w Prawosławnej Akademii Krety w Kolymbari na Krecie pod przewodnictwem patriarchy Konstantynopola Bartłomieja trwały od 19 do 26 czerwca 2016 roku. Recenzowana pozycja Oikonomia kościelna $w$ teorii $i$ praktyce prawosławia jest więc trzecią - i śmiem sądzić, najważniejszą - zamykającą ,prawosławny" tryptyk. Autor zajął się w niej niezwykle aktualnym, równie ważnym, co bardzo trudnym tematem oikonomii. Chociaż w teologii prawosławnej zagadnienie oikonomii zajmuje miejsce szczególne, to jednak nie interesuje wyłącznie tej tradycji teologicznej. Zasada ta jest równie ważna w dialogu ekumenicznym.

Chociaż ważna i aktualna, zasada oikonomii kościelnej jest trudna do zdefiniowania. Również Kościół prawosławny traktował ją bardziej jako praktyczną normę postępowania niż jako temat teologicznych uściśleń i definicji. Z tej też racji prawosławna doktryna oikonomii mimo podejmowanych w tym względzie prób - nie została dotąd formalnie określona na poziomie wszechprawosławnym. Poglądy teologów i kanonistów prawosławnych na ten temat są więc bardzo zróżnicowane. Jak słusznie zauważa krakowski teolog, w ostatnich dziesięcioleciach da się zauważyć wzrost 
zainteresowania prawosławną oikonomią w Kościele rzymskokatolickim. Wpisuje się w to również niniejsza pozycja.

We Wstępie autor słusznie zauważa, że „zasada oikonomii kościelnej spełnia bardzo doniosłą rolę w tradycji wschodniego chrześcijaństwa. Dotyczy to nie tylko teologii czy prawa kanonicznego, lecz przede wszystkim duszpasterskiej działalności Kościoła. W sensie szerszym oikonomia kościelna jest ukazywaniem Boskiej pedagogii zbawienia. W sensie ścisłym stanowi zasadę, która służy jako podstawa do podejmowania wyjątkowych decyzji podyktowanych szczególnymi okolicznościami i konkretnymi potrzebami Kościoła i ludzi. Jako taka jest jedną z dwóch podstawowych norm postępowania w Kościele prawosławnym, którymi posługuje się on w stosowaniu dostępnych sobie środków zbawienia.

o ile tzw. akribeia oznacza dokładne i ścisłe zachowanie norm i przepisów kościelnych, o tyle oikonomia jest czasowym i doraźnym odejściem od ścisłości zastosowania przepisu z racji pastoralnych. Można ją wstępnie określić jako pastoralną postawę Kościoła wobec ludzi, podyktowaną wyrozumiałością, łagodnością, miłosierdziem i troską o ich dobro duchowe. Oikonomia kościelna stanowi jedną z charakterystycznych cech prawosławia, która pozwala w pełni zrozumieć jego specyficzny sposób działania. To działanie według oikonomii obejmuje dziś szerokie obszary życia wewnętrznego prawosławia, jak również w dużej mierze kształtuje stosunek prawosławia do innych wyznań chrześcijańskich. W teologii zasada oikonomii ma szczególne zastosowanie w dziedzinie eklezjologii i sakramentologii. Stąd Georgios Mantzaridis (1935-) może mówić o prawosławiu jako o „Kościele oikonomii" (s. 11).

Ksiądz profesor Kałużny rozważa temat oikonomii w sześciu rozdziałach. Rozdział I: Historyczny rozwój zasady oikonomii kościelnej omawia pojęcie oikonomii w czasach przedchrześcijańskich i w I tysiącleciu chrześcijaństwa, jej rozwój od XI do XIX wieku i debatę na jej temat $\mathrm{w}$ dzisiejszym prawosławiu. W rozdziale II, który dotyczy natury oikonomii kościelnej, autor dotyka problemu „definicji” oikonomii kościelnej, po czym przechodzi do przybliżenia podwójnego wymiaru kościelnej oikonomii. W rozdziale tym podaje również podstawy teologiczne oikonomii kościelnej oraz prawne aspekty oikonomii kościelnej. Rozdział III, noszący tytuł Istotne elementy dynamiki oikonomii kościelnej, omawia cel oikonomii kościelnej, jej rodzaje, szafarza, warunki i obszary jej stosowania. Bardzo ważny jest IV rozdział publikacji, co sugeruje już sam tytuł, który brzmi Wybrane obszary zastosowania oikonomii kościelnej wewnatrz prawosławia. Autor zalicza do nich takie kwestie jak chrzest, 
spowiedź i pokutę, rozwód i powtórne małżeństwo czy wreszcie praktykę postu. Rozdział V, zatytułowany Wybrane obszary zastosowania oikonomii kościelnej $w$ relacjach $z$ nieprawosławnymi, podejmuje zagadnienia międzykościelne. Należy do nich uznawanie chrztu konwertytów na prawosławie, zezwalanie na małżeństwa mieszane czy zezwalanie na wspólną modlitwę z nieprawosławnymi. Rozdział VI, niezwykle ważny i intersujący dla środowisk ekumenicznych, omawia zagadnienie oikonomii kościelnej w dialogu ekumenicznym prawosławia. $W$ rozdziale tym ks. Kałużny porusza kwestię oikonomii w dotychczasowym dialogu ekumenicznym prawosławia oraz stara się spojrzeć na zagadnienie oikonomii w perspektywie przyszłego dialogu ekumenicznego. Zadaje zatem pytanie, czy zasada oikonomii zawiera w sobie ukryty antyekumenizm, czy może jest szansą dla ekumenicznego działania prawosławia? Każdy z sześciu rozdziałów został opatrzony podsumowaniem, całość natomiast zakończeniem, obszerną bibliografią, indeksem osobowym oraz wykazem skrótów.

Uderza niezwykle jasny i logiczny rozkład materiału, bardzo bogata literatura źródłowa, wczytanie się w teologiczną i duchową wrażliwość prawosławia, które od wielu wieków stosuje tę szczególną zasadę miłosierdzia. Krakowski uczony szuka jej biblijnych i teologicznych źródeł, śledzi jej szczegółowy rozwój i szerokie zastosowanie, zarówno wewnątrzkościelne, jak i ekumeniczne.

Pozycja oparta jest na bogatym materiale źródłowym, który obejmuje trzy kategorie: 1) źródła podstawowe; 2) źródła pomocnicze; 3) źródła ogólne. Podstawowe źródła niniejszego studium obejmują dokumenty Kościoła prawosławnego, dialogów międzywyznaniowych z udziałem prawosławia i teksty teologów prawosławnych poświęcone oikonomii kościelnej.

Przypuszczać należy, że recenzowana pozycja, chociaż pióra teologa katolickiego, zostanie przyjęta pozytywnie również przez teologów prawosławnych. Nie ma w niej nic z niezdrowej polemiki, $z$ jednostronnie konfesyjnej krytyki czy nienaukowej nadinterpretacji. Podobnie do wcześniejszych publikacji, jest ona solidną i obiektywną lekturą bogatego materiału źródłowego, który wyszedł spod pióra teologów prawosławnych i wielorakiej aplikacji zasady oikonomii w Kościele wschodnim. Recenzowana publikacja jest poważnym wkładem polskiej teologii w dialog ekumeniczny na poziomie ogólnoświatowym. 